\title{
Enhancing Students' Speaking Skill through Concept Mapping Strategy
}

\author{
Luli Sari Yustina and Mukhaiyar \\ English Deparment \\ Universitas Islam Negeri Imam Bonjol \\ lulyregar@gmail.com
}

\begin{abstract}
This paper discuses the enhancing of students' speaking skill through concept mapping strategy. Speaking skill is one skill to be mastered by university students especially in Speaking III. In this subject, students expressed his thoughts, ideas, opinions, and feelings to others verbally. In other hand, Speaking requires that learners not only know how to produce specific skills of language such as grammar, pronunciation, or vocabulary, but also they understand when, why and in what ways to produce language, level identified three autonomous processing stages in speech production: (1) conceptualizing the message, (2) formulating the language representation, and (3) articulating the message. Concept mapping is been chosen to help them. Concept mapping is a strategy of organizing thoughts in a manner which allows them to flow clearly and logically. The important of concepts many researches such as Skinner, Piaget, and Gagne, believe that concepts and the clarity of them are considered to be essence of any discipline. It added by Novak, Concept Mapping is a strategy for visually representing the structure of information how within a domain are interrelated. The use of concept mapping can give a way to students in representing knowledge. It stated with this strategy, they can help to enrich vocabulary which they need to deliver. In order to achieve this objective, students have been assigned to make concept mapping every meetings. It found there is an enhancing of using concept mapping on developing the learning outcome effectively for speaking
\end{abstract}

Keywords - Enhancing, Concept Mapping Strategy, Teaching, Speaking

\section{INTRODUCTION}

In language teaching the ability to speak can be indicated by mastering pronunciation, grammar, vocabulary, fluency and comprehension (Brown, 1994). In order to make students able to speak English, the teaching of speaking must cover those components. The ability to speak can be developed through some activities in learning process. Those activities are dialogues, plays, free discussions, role-play, story-telling, interviews, reporting, playing cards, picture narrating and describing and also find the difference.

Speaking is an oral productive skill which happens face to face between speaker and hearer (Widdowson, 2011: 57). It is an interactive process to build meaning which covers producing, receiving, and processing information (Burns and Joyce, 1997 : 26). Speaking is one of the four skills that students should master in learning English as a compulsory subject in all levels of education. Many students regard speaking skill measurement of knowing a language. They define fluency as the ability to speak with others. By learning speaking, the students know the way to express opinions, emotions, feelings and ideas meaningfully.

According to Brown (2010: 183) Speaking is a productive skill that can be directly and empirically observed, those observations are invariable collared by the accuracy and effectiveness of a test-takers' listening skill, which necessary compromises the reliability and validity of an oral production test. Speaking is one of the four language skills that play an important role in daily communication. By speaking, people can express their own ideas and helps them to inform something what they think to the others. It is an interactive process of constructing meaning that involves producing and receiving and processing information.

According to O'Malley, et all (200:59), speaking is negotiation of the meaning that is has to be considered someone utterance to get the effect that wanted to listener. it means 'anticipating the listeners' response and possible misunderstandings, clarifying one's own and other's intentions, and arriving at the closest possible match between intended, perceived, and anticipated meanings". Speaking in a classroom entails interacting with the teacher and peers, depending on how classroom activities are organizes.

Strategy is a very important thing in success of teaching and learning. Today, strategy of learning in teaching speaking is more progressive. One of the teaching strategy is using Concept Mapping for increasing the vocabulary. Based on Dillard and Myers (AEC 390: 1) Concept maps are one way to make classroom content easier for students to understand. These educational tools are a great way to simplify information by allowing students to visualize complex processes. They also engage student's creativity and higher order thinking skills.

They also state that Concept maps allow students and teachers to simplify complex information by showing relationships using lines and boxes. Regardless of the type of information being presented, all concept maps have a central idea. Depending on 
the relationship type, a concept map can illustrate a sequence of events, a cycle, or steps in a process. They are visually appealing and convey information quickly.

According to Moreira (2011:6) Concept maps should be collaboratively constructed by the students, who should discuss which concepts are to be included in the map and how these concepts should be organized in the map. They also have to negotiate the linking words that will be written on the connecting lines between concepts. It is in the personal interaction that emerges from the collaborative construction of the maps that lays the great potential of concept mapping as a facilitating strategy for meaningful learning and conceptualization. The teacher, of course, should mediate this interaction. Students start to realize that concepts are relevant elements in the construction of human knowledge and, at the same time, they start conceptualizing - meaningfully constructing key concepts for their own cognitive development - when they draw and re-draw their group concept maps and present them to their peers.

One of the English lecturer (speaking) in Institute for Islamic studies said that students' speaking belong to fair category. Then, the students' fluency, language use, and vocabulary are still low. So, the students' fluency, language, and vocabulary need improvement.

Students are not only expected to speak English, but also speak with good grammar. This is the main problems those make students difficult to speak in English. That's way the good teaching method and strategy are very needed to increase the students' speaking skill.

This is very important for the graduation of English Department Faculty Of Educational and Teacher Training at State Islamic University Imam Bonjol Padang, because they are candidate of the English teachers.

Since the students are hoped to enable to express their meaning in short oral transactional conversations and interpersonal to interact in their community on daily life. It is necessary for the students to master speaking skill. In addition, correction the problem when students speak with their friend is the bad way. It is a principle of learning by doing, it will be given tolerant of the problem has occur. Based on the problem, the writer wants to improve students' speaking by using model that has been chosen. It is Model of Borg and Gall and using Concept Mapping for Teaching and learning Process of Speaking Skill.

The writer chooses the model based on the Joiner and Westphal (1978) the speaking activities must of course be structured, especially at first when student feel quite hesitant about expressing themselves orally. So, using concept map will help students to speak fluently, because they have made a concept before speaking. Then, a person who is communicating with limited linguistic skill has to be willing to use every means at his disposal to clarify the message acting out, writing, drawing, or pointing (Schulz: 1976) so that, the writer wants to give/ ask students to make a concept map before speaking.

Students have to be participated in the various activities in English, especially speaking activity, so that their competency will be good and fluent. In this case, teacher as facilitator, so that, the students have opportunity to express the ideas those they have. Because of it, students need this way to improve their speaking ability. Marianne (2001:105) explains that: "Students need most is extensive authentic proactive in class participation, such as taking part in discussion, interacting with peers and professors, and asking and answering the questions. Marianne (2001:9) states that about teaching activity has to make an appropriate decision about approach, method, technique, and materials those will be used in English class. So that, there are many things those have to pay attention

Holec (1985) on Paul C. Talley (42: 2014) proposed that the teacher could function in a less directive way as a facilitator by personalizing the learning experience through intrinsic motivation and awareness-raising strategies. By making the learning process more accessible (i.e. helping learners to clear away obstacles, find shortcuts, and negotiate difficult passages) to students, the teacher could facilitate planning, independent language learning, self-evaluation, and the acquisition of skills and knowledge.

Based on Paul C. Talley (40: 2014) in classroom communication interaction, EFL students may achieve higher levels of speaking competence through appropriate strategies. Richard-Amato (1996) proposed four strategies for students to learn spoken English:

1. Think of what you are going to say.

2. Think about the structures you are using but do not let them interfere with what you want to say.

3. Do not be afraid to make mistakes (mistakes are normal as you are learning a language).

4. When you are not understood, use repetition, gestures, synonyms, definitions, acting out, whatever comes naturally as you begin to feel more proficient in the language (p. 55).

Based on Dillard and Myers (AEC 390: 1) Concept maps are one way to make classroom content easier for students to understand. These educational tools are a great way to simplify information by allowing students to visualize complex process es. They also engage student's creativity and higher order thinking skills.

Concept maps allow students and teachers to simplify complex information by showing relationships using lines and boxes. Regardless of the type of information being presented, all concept maps have a central idea. Depending on the relation ship type, a concept map can illustrate a sequence of events, a cycle, or steps in a process. They are visually appealing and convey information quickly.

Based on Novak "Concept maps are tools for organizing and representing knowledge. They include concepts, usually enclosed in circles or boxes of some type, and relationships between concepts or propositions, indicated by a connecting line between two concepts." 


\section{METHOD}

This research is undertaken to use Concept Mapping in Teaching and Learning Speaking. To gain the purpose, it is needed a research approach that highlights an effort to produce the interactive in teaching and learning process in the class. Therefore, in designing the model, the researcher uses Research and Development approach by adapting Borg and Gall Model.

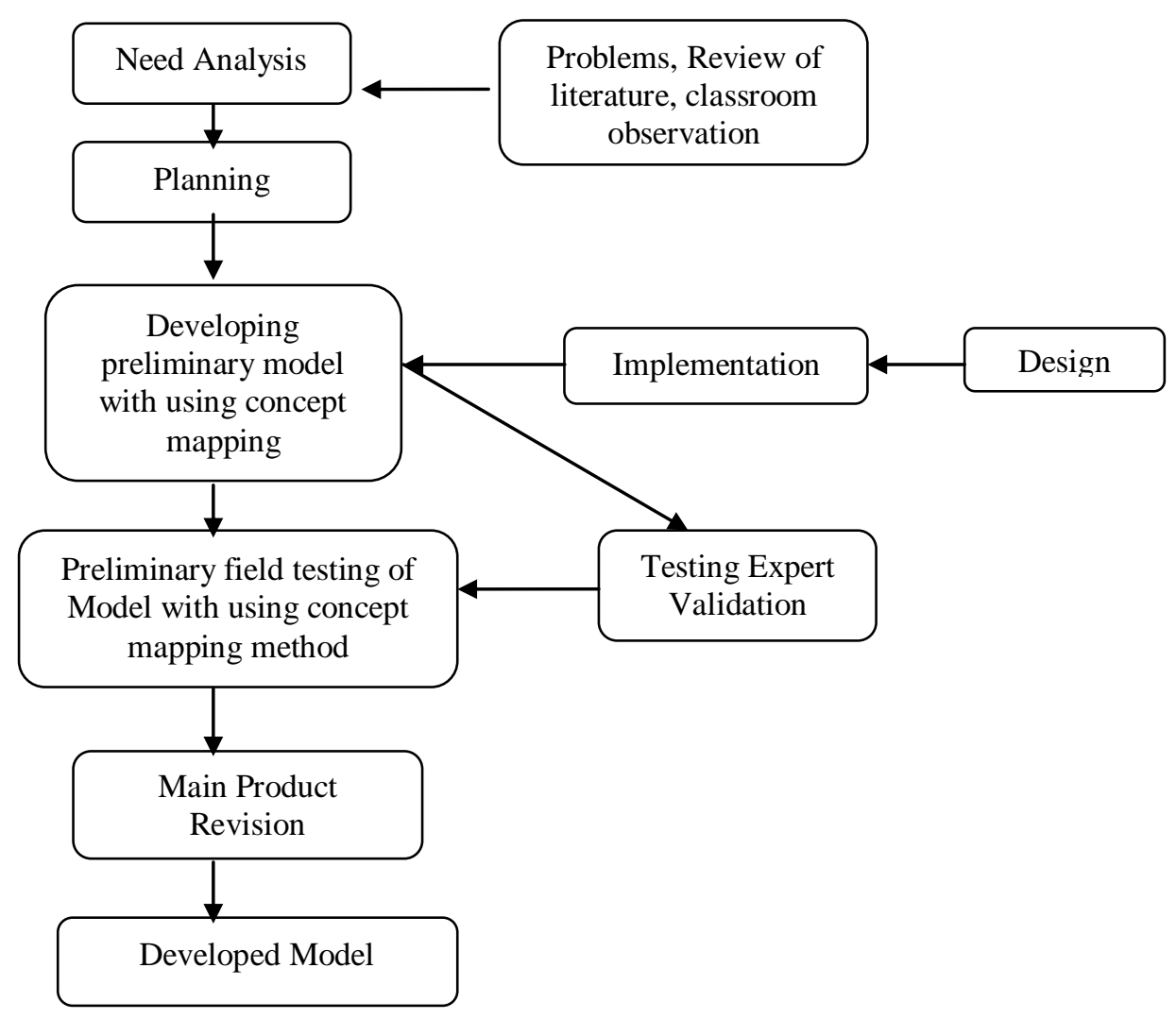

Fig. 1 Borg and Gall model steps scheme

1

This research had been done at English Department Faculty of Educational and Teacher Training at State Islamic University Imam Bonjol Padang. The population of this research is English Department Faculty of Educational and Teacher Training at State Islamic University Imam Bonjol Padang. Sample of this research is English Students, especially Semester IV class A,B, and C. Data collection technique and the research instrument used in this research. The researcher used two data collection techniques namely descriptive qualitative data and quantitative data. Qualitative data and quantitative results were obtained from questionnaire validation expert, reviews of material expert and online media expert. The data were from the field trials obtained from the comments or responses, questionnaire result and test results.

\section{FINDING AND DISCUSSION}

Questionnaire of validation is for instructional design expert and teacher. Questionnaire of validation is made in order that the researcher knows some suggestions and revisions should be made by the researcher. It was created to gather information about validity of the product prototype. Besides, it can help researcher know the weakness of the product. The questionnaire was given to the expert reviewer consisting of instructional design expert and teacher. They assess the prototype and give suggestion to revise the prototype. The test was under took from the questionnaire validation of the test expert. After the test was valid based on the questionnaire validation, the test would be given to the subjects.

Besides data from the result of the test, the documentation was needed to help the researcher run the research. According to Arikunto, the documentation method is used to look for the data concerning matters or the variable that took the form of the note, transcript, book, newspaper, magazine, inscription, notes of a meeting, agenda, etc. The Researcher used the documents related to the object of research such as students' name list and lesson plan.

The purpose of the speaking test was to assess the participants' speaking skills before and after the using concept maps in order to detect the effect of the implementing them on the participants' speaking skills. The participant were pre and post-tested 
orally, and were then tape-recorded by the teachers who evaluated them after each session according to an evaluation scheme presented by the researcher.

\section{CONCLUSION AND RECOMMENDATION}

Based on the result that have been reached in this study; it is safe to say that concept maps have a positive effect on the college level students' speaking skills. This suggestion goes along the positive point of view suggesting that concept maps are very useful and they could help students improve their speaking abilities. To conclude, based on the findings of this study it is recommended that EFL teachers use concept maps in their teaching, since they enhance students' abilities in speaking skill.

\section{References}

Anderson, N. (2003). Practical English Language Teaching. New York: The McGrow-Hill Companies.

Brown.H. Douglas. (2007). Principles of Language Learning and Teaching Fifth Edition. New York:San Francisco Uni

Brown.H. Douglas. (1980). Principles of Language Learning and Teaching Fifth Edition. New York:San Francisco University.

Brown.H. Douglas (2001). Teaching by Principles: An Interactive Approach to Language Pedagogy. $2^{\text {nd }}$ Edition. San Francisco: Longman.

Harmer, Jeremy. (2001). How to Teach English. England: Longman.

Harmer, Jeremy. (2001). The Practice of English Language Teaching. London: Longman.

Harmer, Jeremy.. (2007). The Practice of English Language Teaching. Longman.

Harris, D. P. (2005). Testing English as a Second Language. Bombay: Tata-McGraw Hill \& Co. Ltd.

Hemsley, Michael. (1997). The Evaluations of Teachers' Guides- Design And Application. Retrieved April 3 , 2015 from http://www.elted.net/

Hendriyani, Suswati. (2013). Developing a Model of Learning Strategy of Speaking English at College. International Review of Social and Humanities. Vol. 6. No. 1. 2013. 104-112.

Jörg Müller, Martin Mühlenbrock, Niels Pinkwart, (2004). Towards using concept mapping for math learning Introduction.Duisburg University, Germany Learning Technology newsletter, Vol. 6, Issue 3, July 2004

Joyce, B., Weil, M., and Calhoun, E. (2009). Models of Teaching ( $8^{\text {th }}$ ed.). Boston: Pearson Education, Inc.

J Eppler Martin. (2006). A comparison between concept maps, mind maps, conceptual diagrams, and visual metaphors as complementary tools for knowledge construction and sharing.PalgraveMacmillan Ltd.All r ights $\mathrm{r}$ eserved $1473-8716$ $\$ 30.00$.

Richards C. Jack and Rodgers S Theodore. (2001). Approaches and Method in Language Teaching. Cambridge: University Press.

Romano Jhosep. Creating Online Mind Mapping and Concept Maps.

Van Blerkom, D. L. (1994). College Study Skills: Becoming a strategic learner.Garden Ave Extension. Ithaca: New York 14853$4203 \mathrm{http}: / / w w w .1 s c$. sas.cornell.edu.

W. Davies Martin, Concept Mapping, Mind Mapping and Argument Mapping: What are the Differences and Do They Matter?Australia: The University of Melbourne. wmdavies@ unimelb.edu.au. 